International Journal of Advanced Studies in Humanities and Social Science (IJASHSS)

\title{
Administrative Corruption: Why and How?
}

\author{
Taboli H.R. ${ }^{1}$, Samie'e Darooneh M..,1*, Ehsani A. ${ }^{3}$ \\ ${ }^{1}$ Assistant Professor of Payam e Noor University, Tehran, Iran \\ ${ }^{2}$ Departments of Governmental Management, Faculty of Human Sciences, Kerman Branch, \\ Islamic Azad University, Kerman, Iran \\ ${ }^{3}$ Department of Management, Elm o Farhangh (Science and Culture) University, Kashmar \\ Branch, Tehran, Iran
}

Corresponding Author E-mail: Omidi_0047@yahoo.com

Received: 24 October 2018, Revised: 05 December 2018, Accepted: 20 December 2018

\begin{abstract}
Administrative corruption is a complicated, multidimensional phenomenon created by many reasons resulting in many effects, which is exhibited in a variety of roles and aspects. Considering the importance of this subject in different countries, extensive studies have been carried out in recent years to identify and ascertain the causes of this dilemma. It should be asserted that economic factors are fundamental in any social structure driving people to wrong actions including bribery, embezzlement, and financial corruption. Administrative corruption is a social phenomenon facing all countries of the world. On this basis, various nations with different perception of corruption as an inevitable issue have decided to found their political and institutional structures in a way that least degrees of corruption are observed. International experience suggests that corruption is complex, hidden and diversified. Thus, combating it needs a continuous, lengthy, and difficult process. Corruption is rooted in various backgrounds, which can result in creation and expansion of administrative corruption in potential and actual forms. Using these factors, we can find more effective ways in reducing and eliminating administrative corruption. With regard to the importance of administrative corruption, this paper aimed at exploring how and why administrative corruption exists.
\end{abstract}

Keywords: Administrative corruption, Administrative system, Bribery, Politics, Embezzlement.

\section{Introduction}

Today, organizations are highly susceptible to administrative corruption. IbnKhaldun (1332-1406 AD) paid attention to administrative corruption, and he believed that its main cause is severe enthusiasm of the aristocrats to live in

luxury. In his opinion, high costs of luxurious lives persuade them to approach administrative corruption (Habibi, 1996). Administrative corruption is among those phenomena, which significantly influence the development of countries. Although 
many planning and consideration have been given to this issue, it is still growing in various aspects of the society. To combat administrative corruption, organization experts believe in approaches focusing more on preventing rather than punishing. The term administrative corruption used as an antonym of administrative health, has long been under close attention of organizational intellectuals who made their efforts to eliminate it by proposing definitions in accordance to organizational principles, the common factors of which are bribery and occupational abuses for personal interests. The administrative corruption can lead to challenges and abnormalities such as occupational abuses, bribery and embezzlement, nepotism, injustice, blackmail, dissatisfaction of clients, stealing organizational properties and assets, and sale of confidential information in individual, group and organized forms. In political, economic and management culture of Iran, Fasad e edari (office corruption) is usually used as an equivalent to corruption (Farhad, 1999).

\section{Importance and necessity of the research}

Organizations with healthy organizational systems can lead the societies to productivity and better utilization of human resources, natural resources, technical knowledge, and financial investments as the main factor of any society's success. Corruption in third world has reached a common chronic and critical level. Many criticisms made in the mass media in relation to socioeconomic structures and policies adopted by governmental institutions, indicate that there are still many unsolved problems, which affect administrative corruption indirectly and reduce the efficiency.
Economically, the obtained results show that economic development indices such as GDP, annual per capita production and economic liberalization, regulation quality standard, size of underground economy, social development index, and citizen participation are important and effective parameters in financial corruption. According to the results, improvements in socioeconomic development index, citizen participations, and regulation quality index can improve financial corruption control index (reduction of financial corruption) in selected countries, while increase in the size of underground economy, will increase financial corruption control index (Sinjer, 1999).

\section{History of administrative corruption}

Ancient civilization history studies suggest that corruption is a major factor of collapse of civilizations together with other factors. In other words, corruption is followed by many social disorders, wars, aggressions, rebellions, elimination of infrastructures, and disturbance of societies. Hence, corruption is as old as civilization, which is now a worldwide problem. During centuries and ages, there has always been a reverse correlation between accurate and timely use of power and territories, and corruption. When power was used in a desired manner, corruption declined. In fact, administrative corruption is a double ganger of any political regime. Since the time human activities became organized and coherent, administrative corruption started to be an inseparable part of organizations. Therefore, it can be regarded as an unwanted child created as a result of intraorganizational relations as well as organization-environment relations (Robins, 2005).

Studies of ancient books show that regimes and governments have long been 
facing the problem of abusing of governmental staff and agents and always been concerned about governmental authorities abusing their privileges for personal interests. In other words, corruption has always been a challenge for regimes and an intellectual concern for political thinkers. In $14^{\text {th }}$ century, Dante in Divine Comedy paid attention to corruption, and placed it in the lowest depths of hell. According to Machiavelli, corruption is a current, which weakens moral attitudes and threatens salvation and virtues. Since immoral people are more exposed to corruption, this problem should be resolved by controlling these people and directing intellectual leaders, with the aid of monitoring organizations. The responsibilities and powers legitimately submitted to all government employees pave the way for such abuses. Additional costs imposed by historically experienced financial crimes such as bribery, embezzlement and fraudulent activities on society and government have encouraged political, social and economic experts to pay attention to administrative crimes in recent decades and innovate effective and inexpensive methods to combat it (Mahmoodi, 2003).

\section{Definitions of administrative corruption}

Administrative corruption is defined differently by different societies, cultures and viewpoints. Its root is Rumper meaning "breaking" that is, in corruption process something either breaks or is violated, which it may be an ethical behavior, a legal procedure, or often administrative regulations. According to Gunnar Myrdal, corruption refers to all types of deviation, power abuses or illegitimate use of occupational positions (Robins, 2005).
On other hand, a globally accepted definition by World Bank and Transparency International defines corruption as abuse of administrative powers (public power) in order to gain personal (private) benefits. Based on the definition of corruption by World Bank corruption is abuse of government powers to meet personal needs (Same'e, 2009). In another definition proposed by researchers, financial corruption is a deal between the actors in private and public sectors through which public products are illegitimately changed into private profits (Haji Yousefi, 1999).

\section{The nature of administrative corruption}

Naturally, no human-being is born violator, criminal or sinful, but imbalanced social and economic conditions result in corruption, which in its administrative form threatens governmental and nongovernmental institutions as a result of these imbalanced conditions. Undoubtedly, when there is no social, economic, or political security or hope of having a bright future, self-preservation replaces social security, which persuade individuals, parties and groups to look positively and optimistically at corruption (Tatday, 1999). Administrative corruption is the problem of many societies with a higher rate in some countries and lower in others. Indonesia, India and Vietnam have the most corrupted official systems in the world. In today's consumerist community, there is a growing need for material and the tendency to meet increasing material needs has gone up. As money is the first priority, one who cannot earn further incomes, and legal moneymaking ways are closed to him, how can he fulfill his growing requirements?

\section{Types of admin corruption}


Heidenheimer classifies political corruption to three categories: black, gray and white.

Black administrative corruption is an act blamed by masses and political elites; whose doer must be punished. An example is receiving bribe for neglecting safety standards in construction.

Gray administrative corruption is an act blamed by the majority of elites, but the messes are indifferent about it. An example is delinquency of employees in enforcing laws of lower popularity among people, and only political elites believe in their usefulness.

White administrative corruption is an act apparently against the law, but most members of society, i.e. political elites and the public, do not consider it enough important to be punished. One example is negligence of breaking the regulations, which have lost their necessity due to social and cultural changes. Administrative corruption refers to a situation in an official system which occurs as a result of iterative infringements of the employees, with the possibility of being distributed, and will result in decreased efficiency and effectiveness of the system.

The most common infringements leading to administrative corruption are:
1. Bribery
2. Embezzlement
3. Cheating
4. Blackmail
5. Fraud
6. Extorsion
7. Nepotism
8.Corruption with and without stealing (Rafie'pour, 2000).

\section{Economic rents as a significant index of administrative corruption}

Historically, there have always been privileges and credits given to particular group in many lower developed countries owing to unbalanced and uncoordinated social, economic and official structures as well as high concentration of power, resources and authorities in hands of government. These groups are benefited from rich resources with regard to special social conditions without any useful and constructive activities. Such conditions and availability of such resources for a special group bring incomes in form of economic rents far beyond their eligibility. In other words, income-based rents derived from occupation or ownership is a fundamental right against which the owner gives no help to the society. Or, it is a rent earned for particular reasons through sale of goods and services at costs much higher prices than production costs. A specific feature of governmental rent is that oil-based incomes of oil producing and exporting countries are slightly related to production processes in national economies. Some thinkers set quantitative criteria to extinguish rentier states, i.e. any states $\% 42$ or more of whose revenues are external rents is known as a rentier state (Maadanchian, 2005).

\section{Negative impacts}

Administrative corruption upsets the expenditure budget of a government and persuades it to complex, unjustified, huge investments, which cannot be accurately monitored. On other hand, administrative corruption including employment corruption and employing incompetent human resources decreases the efficiency of the systems in the long run. Corruption also slows down economic growth because it demotivates internal and external investors. Kauffmann (2007) indicates that investment in a relatively corrupt country compared to a non-corrupt one is equal to \%20 surplus investment tax. Corruption lowers legitimacy and efficacy 
of the governments, jeopardizes stability and security of societies, alters democracy and morals, and blocks political and social development of the society (Shokrollahi, 1999). Corruption, by definition, upsets game rules of a society (the institutions) leading to an increase in transaction costs. Increased transaction costs disable investment, production and entrepreneurship, and cripples the economy. Theories have presented somewhat similar definitions of administrative corruption.

For instance, James Scott defines administrative corruption as a behavior in which one serves in a governmental position in order to fulfill his private interests and achieve further well-being or a higher position beyond a formal framework. A preferred definition was suggested by Samuel Huntington, which is presented here with some modifications: administrative corruption is set of behaviors of those public employees who ignore accepted codes and norms towards non-organizational objectives (Klitgaard, 2006). In other words, corruption is an illegitimate instrument to satisfy illegitimate demands of administrative systems. The equations of corruption are as follows:

Corruption $=$ monopoly + concealed power accountability and transparency.

\section{Facilitating agents}

a) Political factors: increasing political and economic corruption is observed in many countries with different economic, social and ideological backgrounds. Thus, it has changed into one of the largest concerns of international community. Today, development economy experts agree that countries relying on raw materials than production are rentier, which distribute incomes from raw material sale in the society and deteriorate the socioeconomic state due to growing corruption. Rentier countries are those which receive the majority of their revenues via external sources in form of rents. The likelihood of arresting and punishing bribers and bribees affects its prevalence.

Lack of full independence of the judicial system, influences of Executive on the judiciary and inspection agencies, pressures of internal and international hardliners, corrupt of hig level managers, propaganda, recommendations for safeguarding the managers from penalties are major political facilitators of corruption.

b) Official factors: ineffective, voluminous and non-proportional administrative structures, complexity of laws and regulations, numerous circular notes and guidelines, ineffective managers, lack of meritocracy, employment discriminations, appointment and promotion of individuals, dysfunction of payroll system, reward and punishment, especially for monitoring and evaluation, preferring group aims to organizational ones, unawareness of clients about official and legal procedures are among such factors.

The most important reasons of ignoring administrative corruption are:

1. Preference of some states to provide money-making opportunities through illegitimate means to their supporters instead of giving legal permits;

2. Family ties;

3. Restriction of private sector;

4. Further urbanization; and,

5. Reluctance of the society to ethical norms (Haji Yousefi, 2007).

Restriction and prevention of administrative corruption 
The researchers mention four groups as conventional methods to prevent administrative corruption:

1-Scientific method deals with conventional branches of science particularly human sciences discussed about how corruption was created, why it appeared and how to combat it (based on scientific findings).

2-Empirical method is based on previous research activities including ups and downs, weaknesses and strengths of preceding actions taken in order to prevent corruption with the aid of these experiences.

3-Moral method, which by referring to religious and national sources, principles of corruption prevention and control are extracted.

4-Comparative method, which takes the experiences of other states, transnational, regional and international bodies into consideration (Ma'adanchyan, 2003).

Actions which reduce the demand of citizens for corrupt services are:

1-Deregulation

2-Rise of public awareness (Habibi, 2009).

Actions which reduce administrative corruption of employees are:

1-Correction of official system

2-Prevention of employment corruption

3-Raise of salaries of governmental employee

4-General monitoring of governmental organizations

5-Formation of independent organizations to combat corruption (Abbasszadegan, 2004).

\section{Method for simultaneous reduction of corruption}

1-Encourage the employees to disseminate and disclose the information; and,

2-Freedom of Press (Abbasszadegan, 2004)

\section{The report of Transparency International on Iran}

According to Transparency International Report 2005, among 159 countries of the world, Iran is rated 93, which has fallen 5 ranks compared to the last year (2004). Transparency International (TI) lists all countries on financial and economic corruption. This report is compiled based on 16 research activities carried out by 10 international organizations. TI ranks corruption between 1 (highest corruption) and 10 (lowest corruption). In Report 2005, Iran was 2.9, which shows no change to 2004. The amplitude of economic corruption in Iran was 2.3-3.3 (Adib, 2009).

\section{Conclusions}

Administrative corruption is a behavior, in which one within an administrative environment focuses on his or others' personal interests, and deviates from the normal official procedure and acts against predetermined objectives of the organization or office resulting in disturbance and losses to the system and ultimately to public interest. Unfortunately, not only does Iranian official system have no help for the national development owing to internal and external organizational issues, but it has enhanced underdevelopment. And despite official revolutions, official modifications, bureaucratic purge, contractions and extensions of national official management, the country still suffers structural and management defects. Administrative corruption is a complex, multidimensional phenomenon with many causes and effects playing different roles in different conditions. With regard to worldwide importance of such issue, extensive studies have been carried out to identify and ascertain causes of this problem. As stated earlier, economic factors are fundamental in any social structure leading individuals to undesirable and illegal activities including bribery, embezzlement, and financial corruption. Administrative corruption is a social phenomenon facing all countries of the world. On this basis, various nations with different perception of corruption as an inevitable issue have 
decided to found their political and institutional structures in a way that least degrees of corruption happen. International experience suggests that corruption is complex, hidden and diversified. In fact, corruption in official and social aspects is like an infection, in case it pervades the body (society); it can disable the body organs one by one and perhaps the entire body. There is a variety of actual and potential factors to emerge, expand and increase corruption. Identification of these factors can be helpful in finding ways for elimination of administrative corruption in the system.

\section{References}

Abbasszadeghan, M. (2004). Administrative corruption. Cultural Research Office, Tehran.

Adib, M.H. (2009). Sociology of Iran. Hasht Behesht Publication.

Agha Bakhshi, A. (2007). Dictionary of political science. $2^{\text {nd }}$ ed. Pegah Publication

Habibi, N. (2005). Administrative corruption (factors and combatting techniques). Asateer Publication

Habibi, N. (2009). Administrative corruption, $1^{\text {st }}$ ed. Vasghi Publication.

Haj Yousefi, A.M. (1999). Rent, Rentier government and rentierism: a conceptual study, Etelaat Siasi and Eghtesadi, no. 126.

Haj Yousefi, A.M. (2007). Government, Petroleum and economic development in Iran, Islamic Revolution Document Center.
Klitgaard, R (2006). What can we do?, UNESCO message, No. 313.

Mahmoodi, A. (2003). Combatting administrative corruption. Imam Khomeini Research Center, Tehran.

Rafiee'pour, F. (2000). Development and contradiction, 1. Sahami Enteshar Company, Tehran.

Rahbar, F., F Mirzavand, G, Zālpour. (2008). Re-identification of financial management: nature, variety, effects and lessons. Jahad e Danshghahi in the University of Tehran.

Robins, A. (2005). Organizational behavior management, Translated by Parsaian and A'arabi, Commercial Study and Research Center, Tehran.

Samie'e, H. (2009). Criminal Law, Sherkat e Matbouat Publication.

Sinjer, M.J. (1999). Human resources management, Translated by Ale Agha F, Governmental Management Education Center.

Shokrollahi, M. (1999). Capacity building for official health, Official system and development, Employment Affairs Organization, Tehran.

Tatady, V. (1999). Corruption, governmental activities and free market. Translated by Aghaee B. Etelaat Siasi and Eghtesadi, no. 150.Vol 14.

How to cite this article: Taboli, H.R., Samie'e Darooneh M., Ehsani A., Administrative Corruption: Why and How?. International Journal of Advanced Studies in Humanities and Social Science, 2019, 8(3), 282-288. http://www.ijashss.com/article_84376.html 